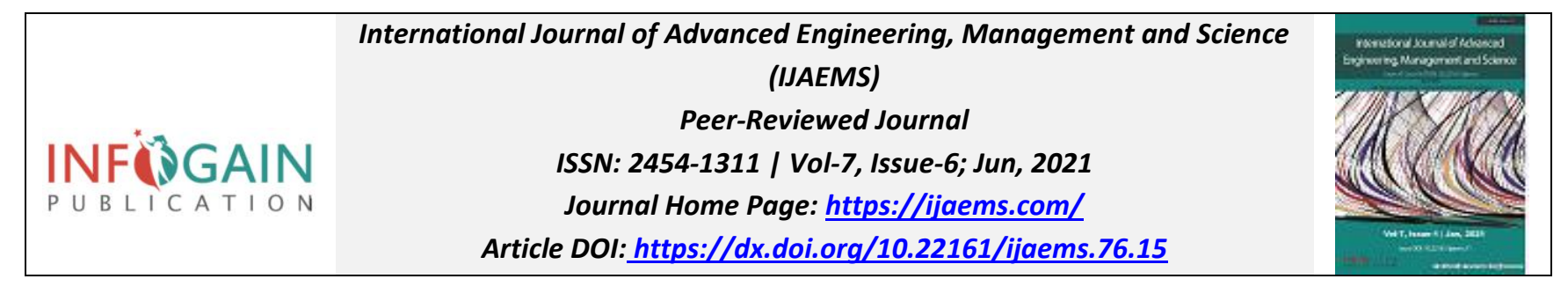

\title{
The Academic Performance and the Computer Programming Anxiety of BSIT Students: A Basis for Instructional Strategy Improvement
}

\author{
Cris Norman P. Olipas*, Rodibelle F. Leona, Andrew Caezar A. Villegas, Angelito I. \\ Cunanan Jr., Charles Lawrence P. Javate
}

College of Information and Communications Technology, Nueva Ecija University of Science and Technology, Philippines
*Email: olipas.cris@ gmail.com

Received: 09 May 2021; Received in revised form: 11 Jun 2021; Accepted: 20 Jun 2021; Available online: 30 Jun 2021

\begin{abstract}
The 21st century has caused numerous significant impacts and advancements in the lives of people. Information Technology (IT) has contributed essential benefits in the different areas of the society. One of the vital skills in developing IT solutions is programming. For many, writing computer programs may be a very challenging task which may result in some levels of anxiety. This study aimed to describe and look at the relationship between the academic performance and the programming anxiety among Bachelor of Science in Information Technology (BSIT) students to provide a basis for instructional strategy improvement in the undergraduate level.

Keywords-Academic Performance, Computer Programming Anxiety, Instructional Strategy Improvement, Programming.
\end{abstract}

\section{INTRODUCTION}

The 21 st century has caused numerous significant impacts and advancements in the lives of people. Advancements have been seen in several aspects of civilization. These progressions call for a new set of relevant skills; thus, the term 21 st century has become a buzzword. Twenty-firstcentury skills are abilities that learners in today's generation must develop and enhance to cope with the fast-changing world. These skills and abilities are essential for learners to succeed in their careers, especially in the Information Age. There are three categories of 21 stcentury skills: learning, literacy, and life skills [1]. Learning skills or the $4 \mathrm{C}$ 's empowers the learners to adapt and improve in the modern working environment by educating them with relevant and significant mental processes such as critical thinking, creativity, collaboration, and communication.

On the other hand, literacy skills include information literacy, media literacy, and technology literacy. These literacy skills are relevant because they enable learners to discern and scrutinize published materials and identify the facts and truths behind them. Lastly, life skills cover the intangible elements of a learner's everyday life, including

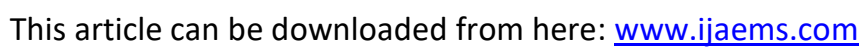

flexibility, leadership, initiative, productivity, and social skills. These skills must be coupled with the learners' ability to use Information and Communication Technology (ICT) tools to thrive in the digital era.

Information and Communications Technology (ICT) has become one of the integral parts of everyday life. This is very evident in the other developments present around. This makes ICT one of the economic development pillars that help gain national competitiveness and advantage [2]. Information Technology is one of the disciplines related to ICT that contributes to understanding the area better. IT is the study of "systematic approaches to select, develop, apply, integrate, and administer secure computing technologies to enable users to accomplish their personal, organizational, and societal goals." [3]. The Information Technology discipline covers the following domains: programming, networking, human-computer interaction, databases, web systems, information assurance and security, and professionalism. These domains require the learners to utilize the essential 21st-century skills mentioned in order for them to succeed in the computing discipline.

This work is licensed under a Creative Commons Attribution 4.0 License. http://creativecommons.org/licenses/by/4.0/ 
Programming is one of the essential domains of Information Technology. It is the process of writing code that instructs a computer on performing and what to perform. Programmers can write a set of procedures and commands that computers understand [4]. In the revised policies, standards, and guidelines for Bachelor of Science in Information Technology released by the Commission on Higher Education through CMO 25 Series of 2015, programming is one of the core courses. This indicates that computer programming is a very relevant course in the computing discipline that learners must genuinely understand, appreciate, and apply to succeed as an IT professional.

A study conducted for non-computer science students has shown that anxiety affects the students' capabilities to learn to program [5]. These programming anxieties contribute to the success of students in a programming course. Another study from Olipas and Luciano (2020) revealed that computer programming anxiety significantly impacts students' sex. Remarkably, the study revealed that female students tend to have higher programming anxiety than male students [6].

This study aims to assess the computer programming anxiety among first-year Bachelor of Science in Information Technology students in a state university and look at its relationship to their academic performance in a computer programming course. The researchers seek to draw new insights and conclusions about computer programming anxiety and students' academic performance, considering that they belong to the 21 st-century type of learners. This study's results are also essential to improve the quality of instructional strategies employed by the teachers to advance further the students' academic performances in computer programming and other ITrelated courses.

\section{Statement of the Problem}

1. What is the Academic Performance of the IT students in CC103 - Computer Programming 2 during the second semester of the Academic Year 2019-2020?

2. What is the computer programming anxiety level of IT students?

3. Is there a significant relationship between academic performance and computer programming anxiety?

\section{METHODOLOGY}

This study applied a quantitative research method in which the researchers performed a structured and organized manner of collecting and analyzing data gathered from different sources [7]. The researchers used a quantitative method to assess the computer programming anxiety of the
BSIT students using a survey instrument. Further, the academic performance was represented quantitatively in grades based on the computer programming course taken during the second semester of the Academic Year 20192020.

One of the research designs of a quantitative method includes a descriptive-correlational research design. Descriptive research design aims to precisely, methodologically, and systematically delineate a population, situation, or phenomenon [8]. By descriptively presenting information, new insights can be drawn. On the other hand, correlational research design measures the relationship of variables to how much extent they relate. It can be a positive, negative, or zero relationship. When conducting correlational research studies, it is essential to consider not controlling the variables subjected to a study [9].

This study was conducted in a state university in Nueva Ecija, Philippines. The researchers specifically administered it in the College of Information and Communications Technology.

In identifying samples for this study; the researchers employed a purposive sampling technique in which the respondents deliberately choose samples based on the following criteria: (1) Students must be a BSIT student; and (2) Students must be enrolled in CC103 - Computer Programming 2 during the second semester of AY 20192020. The respondents were composed of 348 BSIT students. 237 male $(68 \%)$ and 111 female (32\%). 162 or $47 \%$ of them took Technical-Vocational Track with specialization in ICT during their Senior High School education, 86 or $25 \%$ took Accountancy, Business and Management Track, 57 or $16 \%$ took the General Academic Strand, 22 or $6 \%$ took Humanities and Social Sciences Track, and 21 or $6 \%$ took Science, Technology, and Engineering Track.

In carrying out the study, the researchers reviewed existing literature and studies to gather relevant information. The literature and studies served as additional components for a strong foundation for the conduct of this study. The researchers also adapted the instrument used by Olipas and Luciano (2020) to measure the level of computer programming anxiety among IT students [6]. The researchers included additional variables such as academic performance in CC103 - Computer Programming 2 and the students' demographic profile to suit the study's needs. To ensure that the adapted instrument is valid and reliable, the researchers performed a reliability analysis as shown in Table 1. 
Table 1: Reliability Analysis

\begin{tabular}{cc}
\hline Cronbach's Alpha & N of Item \\
\hline 0.854 & 10 \\
\hline
\end{tabular}

Based on the reliability analysis, the computed value of Cronbach's Alpha is 0.854 . This means that the adapted instrument has good internal consistency [10]. The study was conducted at the time of the pandemic. To gather data, the researchers utilized Google forms to reach the respondents. The researchers provided essential information needed in the Google survey form to understand the activity well. The researchers explained to the respondents that the data gathered were treated with utmost confidentiality and anonymity. After data gathering, the researchers treated the data and interpreted them using a rubric presented in Table 2.

Table 2: Rubric for Data Analysis on the Likelihood of Experiencing Computer Programming Anxiety

\begin{tabular}{|c|c|c|}
\hline Range & $\begin{array}{c}\text { Verbal } \\
\text { Interpretation }\end{array}$ & Verbal Description \\
\hline & & This indicates that \\
\hline $\begin{array}{c}3.25- \\
4.00\end{array}$ & $\begin{array}{l}\text { Extremely } \\
\text { Likely }\end{array}$ & $\begin{array}{l}\text { likelihood of experiencing } \\
\text { computer programming anxiety } \\
\text { among students is very high. }\end{array}$ \\
\hline $\begin{array}{l}2.50- \\
3.24\end{array}$ & Likely & $\begin{array}{l}\text { This indicates that the } \\
\text { likelihood of experiencing } \\
\text { computer programming anxiety } \\
\text { among students is high. }\end{array}$ \\
\hline $\begin{array}{l}1.75- \\
2.49\end{array}$ & Unlikely & $\begin{array}{l}\text { This indicates that the } \\
\text { likelihood of experiencing } \\
\text { computer programming anxiety } \\
\text { among students is low. }\end{array}$ \\
\hline $\begin{array}{c}1.00- \\
1.75\end{array}$ & $\begin{array}{l}\text { Extremely } \\
\text { Unlikely }\end{array}$ & $\begin{array}{l}\text { This indicates that the } \\
\text { likelihood of experiencing } \\
\text { computer programming anxiety } \\
\text { among students is very low. }\end{array}$ \\
\hline
\end{tabular}

\section{RESULTS AND DISCUSSION}

The frequency distribution based on the academic performance of the IT students shows that $96.9 \%$ passed the course, $2.0 \%$ unofficially dropped, and $1.1 \%$ got an incomplete mark. Results revealed that most students have satisfactorily passed the course. Different factors affect the academic performance of the students. This includes intellectual level, personality, motivation, skills, interests, study habits, self-esteem, and the teacher-student relationship. Positive impacts of these factors may lead to satisfactory student performance. However, unsatisfactory academic performance is sometimes related to teaching methods [11]. The results provide an opportunity for future studies to look into the underlying factors that affect This article can be downloaded from here: www.ijaems.com students' academic performance. Also, looking at the problems and challenges of the students that lead them to drop the course unofficially may be considered to provide a better understanding of how to craft intervention programs in the future.

\section{The Academic Performance of BSIT Students}

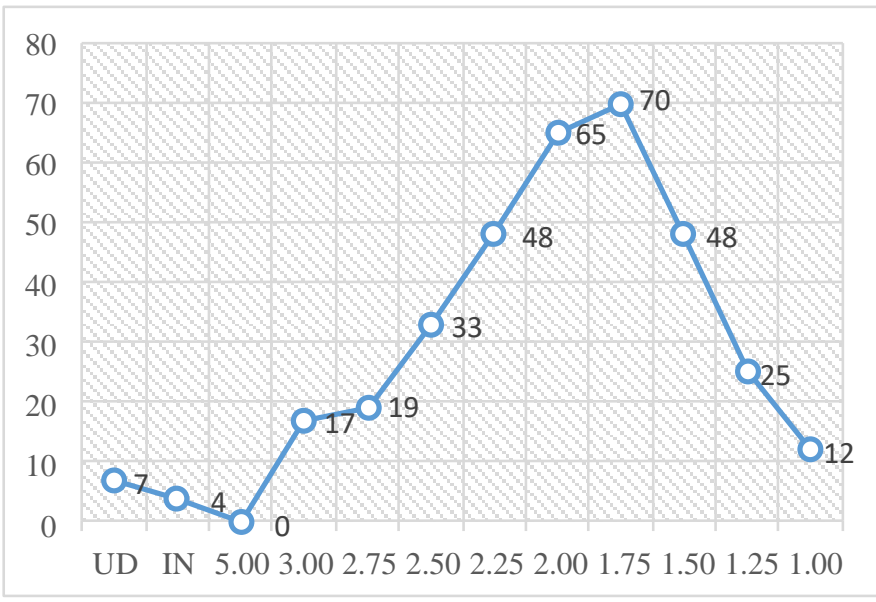

Fig.1: Frequency distribution of Academic Performance of BSIT Students

The Computer Programming Anxiety of IT Students

Table.3: The Likelihood of Experiencing Computer Programming Anxiety among BSIT Students

\begin{tabular}{|c|c|c|}
\hline Item & Mean & $\begin{array}{c}\text { Verbal } \\
\text { Description }\end{array}$ \\
\hline $\begin{array}{l}\text { I feel uneasy about using } \\
\text { programming language }\end{array}$ & 2.39 & Unlikely \\
\hline $\begin{array}{l}\text { Programming terminologies } \\
\text { sound like confusing jargons } \\
\text { to me }\end{array}$ & 2.45 & Unlikely \\
\hline $\begin{array}{l}\text { I have avoided programming } \\
\text { because it is unfamiliar to me }\end{array}$ & 2.54 & Likely \\
\hline $\begin{array}{l}\text { I hesitate to perform } \\
\text { programming activities or } \\
\text { exercises because I fear of } \\
\text { making mistakes I cannot } \\
\text { correct }\end{array}$ & 2.41 & Unlikely \\
\hline $\begin{array}{l}\text { Programming subjects make } \\
\text { me anxious }\end{array}$ & 2.52 & Likely \\
\hline $\begin{array}{l}\text { Working with programming } \\
\text { activities or exercises make } \\
\text { me very nervous }\end{array}$ & 2.39 & Unlikely \\
\hline $\begin{array}{l}\text { I do not feel threatened when } \\
\text { others talk about } \\
\text { programming to me }\end{array}$ & 2.48 & Unlikely \\
\hline $\begin{array}{l}\text { I feel aggressive and hostile } \\
\text { when I think of trying to use } \\
\text { programming }\end{array}$ & 2.48 & Unlikely \\
\hline Programming make me feel & 2.50 & Likely \\
\hline
\end{tabular}

(C)2021 The Author(s). Published by Infogain Publication.

This work is licensed under a Creative Commons Attribution 4.0 License. http://creativecommons.org/licenses/by/4.0/ 
uncomfortable

I get a sinking feeling when I

think of trying to use new

programming language

\begin{tabular}{lll}
\hline Over-all Grand Mean & 2.46 & Unlikely \\
\hline
\end{tabular}

In Table 3, results show that IT students "unlikely" experience computer programming anxiety in general, as reflected in the overall grand mean of 2.46. However, most likely, students have avoided programming because it is unfamiliar to them $(\mathrm{WM}=2.54)$, programming subjects make students feel anxious (WM $=2.52)$, and programming makes them feel uncomfortable $(\mathrm{WM}=$ 2.50). According to Connolly, Murphy, and Moore (2009), one decisive factor concerning the level of anxiety can be attributed to students' perception of their entry-level computer experience and the ability to learn to program [12]. Thus, most likely, students can have difficulties learning programming courses, especially newcomers or first-year college students.

The Relationship between Academic Performance and Computer Programming Anxiety

Table 4: Relationship between Academic Performance and Computer Programming Anxiety

\begin{tabular}{llcc}
\hline \multicolumn{2}{c}{ Factors } & \multicolumn{3}{c}{$\begin{array}{c}\text { Computer } \\
\text { Programming } \\
\text { Anxiety }\end{array}$} & Interpretation \\
\hline \multirow{2}{*}{$\begin{array}{l}\text { Academic } \\
\text { Performance }\end{array}$} & $\begin{array}{l}\text { p-value } \\
\text { correlation }\end{array}$ & .0000 & $\begin{array}{c}\text { Significant } \\
\text { coefficient }\end{array}$ \\
& -0.232 & Relationship \\
\hline
\end{tabular}

**Correlation is significant at 0.01 level (2-tailed)

Table 4 shows the test on the relationship between Academic Performance and the Computer Programming Anxiety of the BSIT students. Results revealed that the academic performance has significant negative relationship to computer programming anxiety ( $\mathrm{p}$-value $=$ $.000, r=0.232$ ). This indicates that the higher the students' academic performance, the lower the likelihood of experiencing computer programming anxiety. Results further reveal that computer programming anxiety negatively affects the academic performance of the students. Moreover, based on the study conducted by Talib and Zia-ur-Rehman (2012), perceived stress was found to have a significant negative correlation with the academic performance of students. Course load, sleep problems, and social activities were the major sources of stress affecting the students' academic performance [13].

\section{CONCLUSION}

This study aimed to identify the academic performance of

This article can be downloaded from here: www.ijaems.com the IT students and its relationship to their computer programming anxiety to provide a basis for improving instructional strategy. Three hundred forty-eight IT students enrolled in CC103 - Computer Programming 2 participated in this study during the Academic Year 20192020. Results revealed that $68 \%$ of the respondents are male, and $32 \%$ are female. Forty-seven percent of them completed Technical-Vocational Track with a specialization in ICT during their senior high school years. The academic performance of the IT students revealed an excellent result based on the analysis, indicating that 96.9\% of them have passed the course. In general, IT students had unlikely experienced computer programming anxiety based on the computer overall grand mean of 2.46 . Results also revealed a negative correlation between their academic performance and computer programming anxiety. This means that the higher the academic performance rating achieved by the students, the lower their computer programming anxiety would be. These results open new opportunities and allowed educators to understand further the impact of programming anxiety on the students' academic performance.

\section{RECOMMENDATIONS}

Based on the findings and conclusions, the following recommendations are drawn:

1. To bridge the gap between the number of male and female enrolled in computing courses like IT, information dissemination on the role of women in computing maybe consider;

2. To further improve the quality of instruction, educators must take into consideration the engaging teaching-and-learning environment to lessen the programming anxiety among students while increasing the level of their participation to improve their academic performance;

3. Future studies involving a more significant number of samples may be considered to understand how the programming anxiety of students in every year level may differ considering the levels of programming courses they take.

\section{REFERENCES}

[1] Stauffer, B. (2020). What are $21^{\text {st }}$ Century Skills?. Applied Educational Systems. Retrieved from https://www.aeseducation.com/blog/what-are-21st-centuryskills

[2] pcdreams (2016). Importane of Information and Communications Technology (ICT) in our daily life. Retrieved from https://www.pcdreams.com.sg/importanceof-information-and-communications-technology-ict-in-ourdaily-life 
[3] Information Technology Curricula (2017). Information Technology Curricula 2017 - ACM. Retrieved from https://www.acm.org/binaries/content/assets/education/curri cula-recommendations/it2017.pdf

[4] Stokdyk, D. (2020). What is Computer Programming and How to Become a Computer Programmer? Retrieved from https://www.snhu.edu/about-us/newsroom/2018/06/what-iscomputer-programming

[5] Figueroa, R. and Amoloza, E. (2015). Addressing Programming Anxiety among Non-Computer Sciene Distance Learners: A UPOU Case Study. International Journal for Educational Media and Technology. Vol. 9 No. 1 pp 56-67

[6] Olipas, CNP and Luciano, RG. (2020). Understanding the Impact of Using Countdown Timer on the Academic Motivation and Computer Programming Anxiety of IT Students: The Case of A State University in the Philippines. International Journal of Scientific and Technology Research. Vol. 9 Issue No. 3, ISSN 2277-8616

[7] SIS International Research (2020) https://sisinternational.com/what-is-quantitative-research

[8] McCombes, S. (2020). Descriptive Research. Scribbr. Retrieved from https://www.scribbr.com/methodology/descriptive-researh

[9] McCombes, S. (2020). Correlational Research. Scribbr. Retrieved from https://www.scribbr.com/methodology/correlationalresearch

[10] Stephanie Glen (nd). “Cronbach's Alpha: Simple Defintion, Use, and Interpretation”. StatisticsHowTo.Com. Retrieved from www.statiscshowto.com/probability-andstatistics/statistics-definitions/cronbachs-alpha-spss.

[11] Lamas, H. (2015). School Performance. Propósitos y Representaciones, 3(1), 313-386. doi: http:// dx.doi.org/10.20511/pyr2015.v3n1.74

[12] Connolly, C., Murphy, E., \& Moore, S. (2009). Programming Anxiety Amongst Computing Students-A Key in the Retention Debate? IEEE Transactions on Education, 52(1), 5256. doi:10.1109/te.2008.917193

[13] Talib, Nadeem and Zia-ur-Rehman, Muhammad (2012). Academic Performance and perceived stress among university students. Academic Journals. Vol 7. pp. 127-132. Doi.org/10.5897/ERR10.192 